[Published in The Routledge Handbook of Libertarianism, ed. Jason Brennan, David Schmidtz, and Bas van der Vossen (Routledge, 2017), pp. 259-71. Official version:

https://www.routledge.com/The-Routledge-Handbook-of-Libertarianism /Brennan-van-der-Vossen-Schmidtz/p/book/9781138832169.]

\title{
Is Wealth Redistribution a Rights Violation?
}

\author{
Michael Huemer
}

\section{The Prima Facie Case}

Most theories of distributive justice call for coercive redistribution of wealth on the part of the state - on these views, the state should take money from the relatively wealthy, presumably via taxation, to enrich the relatively poor. ${ }^{1}$ On its face, such redistribution would seem to be a violation of the property rights of the relatively wealthy. Suppose that an ordinary person, say, you, were to coercively extract wealth from person $\mathrm{A}$ in order to give it to person $\mathrm{B}$. There is no unusual relationship between $\mathrm{A}$ and $\mathrm{B}-\mathrm{A}$ did not steal the money from $B$, nor did A do anything special to incur a debt to B; your sole reason for targeting $\mathrm{A}$ is that $\mathrm{A}$ has much more wealth than $\mathrm{B}$. You threaten A with kidnaping and imprisonment to induce $A$ to hand over the money, which you then give to B. We would normally consider your action to be wrongful and a violation of A's property rights. So at least on its face, it would seem that it would also be a wrongful violation of property rights for the state to forcibly redistribute money from $\mathrm{A}$ to $\mathrm{B}{ }^{2}$

In what follows, I am interested in addressing one kind of response to this argument. I shall not address views according to which the wealth redistribution is not a rights violation because there are no private property rights. Nor shall I consider views on which the redistribution is permissible because those who are expropriated are guilty of some wrong that calls for either punishment or restitution. Nor, finally, shall I consider views on which redistribution is a justified rights violation, perhaps because the property rights of the wealthy are outweighed by more important moral considerations. ${ }^{3}$

The type of response I am interested in maintains, rather, that even if private property in general is legitimate, and even if the wealthy as a class are not guilty of wrongdoing, coercive redistribution from the wealthy as a class to the poor as a class is nevertheless not a violation of the rights of the wealthy. I shall address three ways of defending that view, each of which fails. My conclusion will be that the initial appearance that large-scale wealth-redistribution programs are rights-violations remains undefeated.

\footnotetext{
${ }^{1}$ Rawls 1999; Murphy and Nagel 2002; Holmes and Sunstein 1999. The intended sense of "redistribution" here is descriptive, rather than normative; thus, taking wealth that A possesses and giving that wealth to B counts as "redistribution," regardless of whether A is or ever was justly entitled to that wealth. For different senses of "redistribution," see Barry 2014.

${ }^{2}$ Nozick 1974, pp. 167-74.

${ }^{3}$ For this last view, see Nagel 1981, p. 196; Wellman 2005, pp. 21-2; Scanlon 1981, pp. $115-$ 16. In truth, I find this sort of view the most plausible way of defending wealth redistribution. For discussion, see my 2013, pp. 148-60.
} 


\section{How the Individual's Production Depends on Others}

\subsection{You Didn't Build That}

During a 2012 campaign speech, President Barack Obama explained part of the rationale behind his belief that wealthy Americans should pay higher taxes:

If you were successful, somebody along the line gave you some help. There was a great teacher somewhere in your life. Somebody helped to create this unbelievable American system that we have that allowed you to thrive. Somebody invested in roads and bridges. If you've got a business - you didn't build that. Somebody else made that happen. ${ }^{4}$

Though the "you didn't build that" remark became fodder for negative campaign ads from his opponent, Obama's remarks nevertheless point toward an interesting argument.

Leave aside the question of what exactly President Obama was getting at. The question that concerns me is whether some argument in this neighborhood could be used to defend wealth redistribution against the charge of violating property rights. Suppose, in accordance with a broadly Lockean account, that property rights in material goods are founded ultimately on the individual's ownership of his own labor (perhaps because one comes to own that with which one "mixes one's labor," or simply because one deserves to profit from the value one's labor produces). ${ }^{5}$ The observation that, for example, an individual business owner does not build a business solely through his own work would then seem at least to weaken his ownership claim on that business. If the business was also produced in part by the labor of others, then it would seem that those others, too, would have some claim on the business. This, in turn, would give those others some claim on the profits produced by the business. Whatever claims on those profits others might have, it might be thought that the government may approximate to satisfying those claims through wealth redistribution programs.

What about the case of individuals who, despite owning no physical capital, become wealthy simply because their labor is highly economically valuable, for instance, doctors and lawyers? One might argue that the individual's capacity to perform economically valuable labor is itself partly a product of the beneficial actions of others, thus giving those others some claim to the fruits of that labor. Be that as it may, I shall focus on the initially stronger case for redistributing (some of) the wealth of business owners.

\subsection{Individual Contributors}

Assume that I run a business manufacturing iPods. An iPod comes off the assembly line. Who made it? A great many people contributed: the person who runs the business (me), the investors who provided the capital to start it, the employees who wrote the software for the iPod and operated the machinery to produce it, the suppliers from whom I bought the components, their suppliers, the truck drivers who brought the

${ }^{4}$ C-SPAN 2012.

${ }^{5}$ Locke 1980, section 27, p. 19. 
components to my factory, the road workers who built the roads on which those trucks drove, the farmers who grew the food to feed the truck drivers, and so on. In the end, when any economic good is produced, an enormous number of individuals will typically have contributed to it.

What claims do these contributors have on the final product? Presumably not everyone has an equal claim on it. Is there some way of measuring the contribution made by each, so as to assign each contributor her fair share of the profit? More to the point, is there reason to believe that the low-income contributors have been systematically shortchanged (paid less than proportionately to their contribution), such that general redistribution from high-income to low-income individuals would be justified in terms of Lockean or quasi-Lockean norms governing property rights? There are two reason to doubt that:

(i) First, ordinary market mechanisms tend toward distribution approximately in accordance with an approximately fair principle: namely, the principle that individuals be rewarded according to their marginal contribution to the economic value of the finished product.

Why does the market tend to distribute rewards in this way? In standard price theory, buyers buy a good up until the point at which the buyer's marginal utility from acquisition of the good equals the price to be paid. This applies as well to such productive factors as labor and financing as to material products. Thus, in theory the salary received by an individual worker (plus other employment costs such as payroll taxes and benefits costs) should equal the marginal value of the worker to the employer. Roughly, the reason for this is that (a) labor has diminishing marginal value, (b) if the marginal value to the employer of an individual worker is less than the price paid by the employer, then the employer increases his profit by firing one or more workers, and (c) if the marginal value of the worker is greater than the price paid by the employer, then the employer increases his profit by hiring more workers. Thus, in equilibrium, the worker receives his marginal economic product.

Why is this kind of distribution fair? For concreteness, suppose that Sam belongs to a company that takes in $\$ 1,050,000$ in revenues per year. Without Sam, the company would only take in $\$ 1,000,000$ per year. So Sam's marginal economic product is $\$ 50,000$. But suppose Sam's annual salary is $\$ 60,000$ (assume this includes all the costs involved in employing Sam). Then Sam's presence is a net cost to the rest of the participants; the others could all be made better off by expelling Sam and dividing the extra $\$ 10,000$ that would then be available among themselves. ${ }^{6}$ But it is not reasonable for Sam to expect to be included in a joint venture for economic profit, under such conditions. For this sort of reason, in general, no person can reasonably ask for more than their marginal economic product, when engaged in cooperative economic activity with others.

Thus, market distribution, which approximates to distribution in accordance with marginal economic product, gives each participant, approximately, the most that they could reasonably ask for (given who the other participants are, and given an economic purpose for the cooperation).

${ }^{6}$ That is, a proposal to expel Sam and redistribute revenues could be made, such that every other person in the company would be made economically better off under that proposal. 
(ii) More importantly, we should question the need for some agent outside the production process to evaluate each individual's contribution. Individuals involved in economic activities are normally compensated for their contributions, by the other participants, at a rate mutually agreed upon. These agreements obviate any property claims that individuals might otherwise have to the products that (partially) result from their activities.

For example, suppose that I hire a truck driver, at a rate mutually agreed upon in advance, to bring supplies to my factory. I then use these supplies to create highly valuable iPods, which I sell for a large profit. The truck driver, despite having causally contributed to producing the iPods, has no ownership stake in them, because no such stake was specified in our agreement. That is, the driver agreed to sell his labor to me in return for a certain sum of money, which, we assume, I have paid. Whatever benefit I subsequently derive from that labor is then mine alone. The driver could have insisted, in exchange for his labor, on receiving a percentage of the profits from my business. But assume he did not do so. In that case, the driver's ownership of his own labor gives him no claim on the profits of the business, since the driver already sold his labor to the business owner.

Compare a similar case: Susan sells a painting to Jack, who then resells the painting at a profit. Jack does not then have any obligation to split the profits with Susan. The profits are entirely his, because Susan, in the original sale, transferred all claim on the painting; that is what it meant to sell the painting.

Similar observations would apply to other individuals involved in the production process: provided that they received that for which they agreed to sell their labor, no additional compensation is owed.

\subsection{The Contribution of the State}

The preceding discussion may seem to miss the point. The main emphasis in Obama's "you didn't make that" speech was on the contributions to productivity by the state. He mentions teachers, roads, and bridges, before explicitly ascribing the creation of the internet to the government. ${ }^{7}$ Others would emphasize the role of the state in providing law and order, and especially in protecting property rights, which are essential to economic productivity. ${ }^{8}$ In return for its contributions to economic productivity, and to the welfare of society in general, the state is entitled to demand a certain payment.

One might object that, on this reasoning, the state is entitled to demand payment for the specific services mentioned - for instance, the state may require payment for the hiring of police officers, judges, and prosecutors, the construction of roads, and other expenses necessary to the provision of goods that benefit all citizens. But no considerations about the contribution of roads, schools, and law and order to economic productivity could explain why the state is entitled, in addition, to charge the wealthy for "services" that they do not want and do not benefit from, such as social welfare

${ }^{7}$ Immediately following the remarks quoted earlier, Obama continued, "The Internet didn't get invented on its own. Government research created the Internet so that all the companies could make money off the Internet."

${ }^{8}$ Murphy and Nagel 2002, pp. 32-3; Holmes and Sunstein 1999, ch. 3. 
programs for the poor.

In response, it might be held that the entire tax bill paid by a wealthy individual is the charge for the services received by that taxpayer. This may be true even if some of the tax revenues will be used to provide other services. Compare this case: I sell you a book for $\$ 30$. After the exchange, I donate $\$ 10$ of the $\$ 30$ to the Against Malaria Foundation. You complain that you didn't want to support AMF, and that I had no right to charge you for Malaria prevention. You request a $\$ 10$ refund. My response: "I charged you $\$ 30$ for the book, which you received. What I did with the money subsequently was my business." Similarly, the state might say to wealthy taxpayers: "Your tax bill is what we are charging you for the provision of law and order, which you have received. What else we do with the money is our business."

There is, however, an important disanalogy between my book sale and the state's "sale" of law and order. When I sell my book, so we assume, I do not compel you to buy it, nor do I coercively prevent you from buying other books from other authors. The state, however, compels its customers to buy its services at a price set by the state, and it coercively prevents individuals from obtaining those services from any other providers (if someone tries to set up a competing government or government-like entity, the existing government will shut it down with prejudice).

Assume for the sake of argument that the state's coercive, monopolistic behavior here is justified, perhaps because the behavior is necessary to prevent consequences sufficiently dire as to outweigh individuals' prima facie rights against coercion. The point is that the coercive source of the state's revenues nevertheless imposes restrictions on how those revenues may be used, restrictions that would not apply to revenues gained by voluntary trade. If one's entire revenue stream is coercively collected, then any decision that necessitates an increase in revenue collection entails an additional prima facie rights-violation, or an increment in the seriousness of existing rights-violations. By contrast, no such increment in rights-violation is implied in a mere raising of the price of a product that is voluntarily purchased.

Compare the following pair of cases:

Hotwired Car: Jon suffers a medical emergency, which requires him to be immediately driven to the local hospital. The only available person who can drive Jon to the hospital is Sue, and the only available vehicle is a car belonging to someone else, who cannot presently be contacted for permission. Sue hotwires the car and takes Jon to the hospital. Then, for entertainment, she takes the car for a spin up in the mountains before returning it.

Rented Car: As above, except that Sue has rented a car from Avis, which she uses to drive Jon to the hospital. After delivering Jon, she takes the car for a spin up in the mountains.

In the first case but not the second, Sue's drive up in the mountains is a violation of the property rights of the car owner, regardless of whether her use of the car to take Jon to the hospital was justified, and regardless of whether the latter was a rights violation. This is because the drive in the mountains constitutes an additional unauthorized use of the car-owner's property.

Similarly, regardless of whether the state is justified in taxing citizens to pay for 
provision of law and order, the additional seizures of funds required for wealth redistribution would be rights violations, even though similar revenue collections would not violate rights if the state's services were sold voluntarily.

\subsection{The Counterfactual Test}

In determining whether an action on the part of A has violated B's property rights, we might apply a counterfactual test: what property would B have had if A had not acted as he did? If A has violated B's property rights, specifically by stealing from B, it ought to be true that if A had not performed the action in question, B would have possessed some property that he does not in fact possess - we might think this a necessary (though of course not sufficient) condition for there to have been a theft.

In the case of taxation, the question would become: if there were no taxation, what would our incomes be? But if there were no taxation, the government would collapse, at which point (allegedly) all social order would break down. Then no one would have any income (or at least, almost everyone would have much less income, and perhaps none in the form of money). So we would not have more money if not for taxation; therefore, taxation does not violate our property rights in our money. ${ }^{9}$

One problem with the preceding argument is that it applies the counterfactual test very broadly, asking what one's income would be if no one had paid any taxes. Compare this scenario: I run a security company that specializes in preventing burglaries. Ironically, someone breaks into my company's office and takes $\$ 500$, which came from the company's profits. When I catch up with the alleged thief, he offers this defense: "If there were no burglaries, your anti-burglary company would never have gotten off the ground; as a result, you would never have had that $\$ 500$ in the first place. Therefore, my burglary does not violate your property rights in that money." Presumably, if some counterfactual test is correct, the correct reply would be that the burglary violated my property rights because I would have the $\$ 500$ if that specific burglary had not occurred; it does not matter what would have happened if burglary in general did not exist.

Similarly, then, if we want to know whether a specific individual's property rights are violated when that individual is taxed, the appropriate question seems to be what that individual's income would be if that particular instance of taxation had not occurred - that is, if that individual were not subject to that tax on that occasion. The answer is typically that the individual would have more money; thus, individual instances of taxation pass the counterfactual test for constituting property rights violations.

But the more important problem is with the counterfactual test itself. An agent can be guilty of a property-rights violation even if the rights-violator renders his victim better off, and indeed even if the rights-violator enables the victim to obtain the very resources that the rights-violator subsequently seizes. Suppose, for example, that I force you to buy some yarn from me. This is a rights violation; specifically, it is a (rather odd) form of theft. But suppose you subsequently knit the yarn into a sweater, which you sell for a profit. My earlier extortion does not cease to be a rights violation, nor the money I hold cease to be stolen money, merely because you subsequently made good use of the yarn. Now assume that I continue to extort you in the same manner over a period of

\footnotetext{
${ }^{9}$ Murphy and Nagel 2002, p. 32; Zelenak 2003, pp. 2261-2.
} 
time; that you continue to make the yarn into colorful sweaters and scarves, which you sell for a profit; and that you use the proceeds from these sales to satisfy my extortionary demands (which still leaves you with a net profit). Still - even though the money I take from you is money you would not have earned but for the yarn I provide you $^{10}$ - no one would deny that I am violating your rights.

Why is this a rights violation? It is not a rights violation because some counterfactual conditional is true - for instance, that you would be better off, or that you would have more money, if I did not act as I do. It is a rights violation because it is a coerced transfer of a possession (your money) in which you have a property right. The reason you have a property right in the money is that you acquired it in a legitimate manner without violating anyone else's rights. ${ }^{11}$

Likewise, what makes taxation a property rights violation is not that we would have more money if there were no taxes. What makes taxation a property rights violation is that it is a coerced transfer of goods that (in most cases) individuals acquired in legitimate ways. Taxation does not cease to be a violation of taxpayers' property rights merely because the state provides services necessary to economic productivity, even if these services enable individuals to earn the very funds that the state takes.

\section{A Reductio of the Libertarian Argument?}

The preceding argument turns on the state's coercive manner of collecting revenues. Thus, the conclusion would seem to be not merely that redistribution violates property rights, but that taxation violates property rights. But taxation is used to fund virtually all functions of government, including the functions that most libertarians accept as legitimate, such as police, courts, and the military (the minimal state). One might therefore be tempted by the following modus tollens argument:

1. If taxation to fund wealth redistribution is a rights violation, then taxation to fund even a minimal state is a rights violation.

2. But taxation to fund a minimal state is not a rights violation.

3. Therefore, taxation to fund wealth redistribution is not a rights violation either. ${ }^{12}$

Since libertarians seemingly accept premise (2), and the central argument to show that redistribution violates rights would seem to support (1), the libertarian argument is in trouble.

Libertarians should respond by rejecting (2). Taxation is a rights violation, even if the revenues are used solely to finance a minimal state. Taxation is a non-voluntary transfer of property that initially belongs to the taxpayer - anyone who accepts the libertarian critique of wealth redistribution should agree with that statement. And this makes taxation a violation of property rights, whatever the state does with the money

\footnotetext{
${ }^{10}$ Of course, the money I take at a given time is money that you have because of my past extortionary activities, not because of my present act of extortion. This does not falsify the analogy, since the analogous point also holds for the case of taxation by the state.

${ }^{11}$ Nozick 1974, pp. 150-55.

${ }^{12} \mathrm{Cf}$. the argument of Holmes and Sunstein (1999).
} 
subsequently.

How, then, could a minimal state legitimately fund itself? There are at least three reasonable libertarian replies to this: first, one could join the anarchists in denying that even a minimal state is justified. Libertarian anarchists propose, instead, that the traditional functions of the state should be privatized, that is, taken over by protection agencies and arbitration agencies operating in a competitive market. ${ }^{13}$ Second, for those uncomfortable with anarchism, one could propose voluntary methods of financing the minimal state, such as user fees. Third, if one considers both anarchism and voluntary financing of government unfeasible, one might argue that although taxation is a rights violation, it is a justified rights violation since it is necessary to prevent something much worse from happening. On this last view, the justification of taxation will depend upon what the tax revenues are to be used for. It may be, for example, that violating property rights is justified to prevent the complete breakdown of social order, but not justified to prevent a small percentage of society from living in poverty. I shall not pursue these ideas here, however; for present purposes, I rest with the conclusion that taxation, whether justified or not, is a rights violation.

\section{The Role of the State in Defining Property Rights}

Thomas Nagel and Liam Murphy hold that property rights are created by the state, and therefore that the state may simply choose to define property rights in such a way that the money taken from taxpayers never really belonged to them in the first place - that a certain portion of one's income, for example, is the property of the state from the beginning. In that case, tax collection, rather than violating the property rights of individuals, would actually serve only to enforce the property rights of the state. ${ }^{14}$

There are at least three broad views one might take concerning the foundation of property rights:

a. The Pure Natural Rights View: Property rights are moral rights that are, in every aspect and detail, independent of social conventions, laws, and the state.

b. The Extreme Legalist View: Property rights are in every aspect and detail dependent on government-created laws. ${ }^{15}$ (N.B., property rights are not only legal but also moral rights; this is why theft is not just illegal but unethical. The Legalist View is not merely that certain legal rights are dependent on laws, but that the relevant moral rights are dependent on laws.)

c. The Moderate View: Certain broad aspects of property rights are natural, that is, independent of conventions and laws; however, other aspects and details of

${ }^{13}$ See Huemer 2013, especially chs. 10-12.

${ }^{14}$ Murphy and Nagel 2002, p. 58. Murphy and Nagel describe the conventionalist view of property as "perfectly obvious" (p. 8) and "common sense" (p. 74), though they find that ordinary people (including, presumably, Lockean rights theorists) suffer from the "illusion" (p. 74) of natural property rights. Though Murphy and Nagel speak of conventions, their argument requires that property rights depend not merely on conventions, but, more specifically, on government-created laws.

${ }^{15}$ Holmes and Sunstein 1999, pp. 59-60. 
property rights must be settled by conventions or laws.

Which of these views are plausible, and which might be used to support the NagelMurphy argument in defense of taxation?

Begin with the Pure Natural Rights View. This view obviously conflicts with the Nagel-Murphy argument. The Pure Natural Rights View, however, is also highly implausible on reflection. Consider an example from David Friedman: if I fire a thousand megawatt laser at my neighbor's house, I thereby violate his property rights. On the other hand, if I turn on a lamp in my house, knowing that some photons will go out the window and hit my neighbor's house, I do not thereby violate his property rights. The only physical difference between these two actions lies in the number and energy levels of the photons that I send my neighbor's way. ${ }^{16}$ So there must be some principle governing the number and energy levels of photons that one may send onto another person's property (of course, the principle need not be formulated in those terms): there is some amount of light at which it first becomes a rights-violation. But it is not plausible that this is determined purely by natural law. We need some sort of convention or man-made law to settle the matter.

For a second example, I have the right to demand that United Airlines not fly commercial jets 500 feet over my home; thus, some rights over the overlaying airspace seem to be included with one's ownership of a piece of real estate. But I do not have the right to enjoin United from flying airplanes 20,000 feet above my home. Exactly how high, then, must an airplane be for it to not be violating my property rights? Again, it is not plausible that this is settled purely by non-conventional, objective moral principles.

We might be tempted, then, by the Extreme Legalist View: perhaps all questions about property rights are to be settled by government-made laws. Again, the claim here would not be the trivial one that the legal questions are settled by laws, but the ambitious claim that the moral questions as to one's property rights are entirely settled by laws. This view can be broken into two component theses:

i. Laws that recognize a particular set of property rights are necessary for the existence of moral property rights; without legal rules governing property, there would be no property rights.

ii. Laws that recognize a particular set of property rights are sufficient for the existence of moral property rights; for example, the existence of such conventions or laws makes it pro tanto morally wrong to take, damage, or use an item that, according to the conventions, belongs to another person, without that person's permission.

Nagel and Murphy need both theses: they need thesis ( $(2)$, to argue that individuals have no moral right to the money that the state takes in taxes; and they need thesis (ii), to argue that the state has a right to that money (otherwise, it won't be wrong to fail to pay one's taxes).

Both theses are implausible. Begin with (i), the idea that laws are necessary for

${ }^{16}$ Friedman 1989, p. 168. 
property rights. Suppose you are exploring a remote wilderness region outside the jurisdiction of any government, when you come upon a clearing containing a rude hut. The hut appears to have been built by a hermit, who is its only inhabitant. Since property rights depend entirely upon governmental laws, and none are in force here, you determine that the hermit does not own the hut. Over his vociferous protestations, you decide to spend the night in the hut, eat some of the food that the hermit has grown and gathered, and then paint the hut lime green. You don't need to do any of these things; you just do them for fun. If there really are no property rights in this situation, you have just as much right to do these things as the hermit does. ${ }^{17}$ Notice that my claim is not that in this scenario, the hermit has the full set of property rights exactly as they would be if a U.S. citizen bought some land in the United States and built a house on it. My claim, in accordance with the Moderate View of property rights, is only that there is at least some elementary, core notion of property that applies in the scenario.

Next, consider thesis (ii): that certain kinds of laws are sufficient for property rights to exist. In the pre-Civil War U.S., ownership of human beings was recognized in the southern states, both conventionally and legally. Thus, thesis (ii) would imply that a slave was genuine property of his master, in a morally loaded sense. This need not preclude the possibility of arguing that some other distribution of property would be preferable (perhaps one in which no one were assigned a property right in another human being). But, given the laws as they were, one would have to say that a master in fact had the moral rights regarding his slaves that go along with property - the right to determine how his slaves were used, to sell them, bequeath them, and so on - and that for a slave to escape from his master, or for a third party to help a slave to do so, was an act of theft. I find this implausible. I do not think merely that the rights of the master would be outweighed by other moral values, such that the theft would be justified all things considered; I think it implausible to view runaway slaves and those who helped them as violating any moral rights at all.

Perhaps Nagel and Murphy would wish to qualify thesis (ii): perhaps legal recognition suffices for generating genuine (moral) property rights only if the system as a whole is overall reasonably just, beneficial, or satisfies some other norms (where these are norms that are independent of property rights). This would be in keeping with their frequent insistence that questions about tax policy must be addressed by evaluating the justice of the overall distribution that results from the political system as a whole, including both tax policy and all the various government programs. Perhaps during the slavery era, the overall system was sufficiently unjust, due to its violating some independent norms, ${ }^{18}$ that it failed to generate genuine property rights. But while this would explain why helping runaway slaves to escape was not a rights violation, it fails

\footnotetext{
${ }^{17}$ Cf. Scanlon 1981, p. 124. Unlike Scanlon's example, my example does not involve serious harm to the hermit (and there is no general norm independent of property rights against causing small harms of the sort in my example), so the wrongness of the action cannot be said to derive from a general norm against harming others. It seems to derive from something like a valid property claim on the part of the hermit.

${ }^{18} \mathrm{Of}$ course, Murphy and Nagel could not, on pain of begging the question, claim that the system was unjust due to its violating the norms governing property rights. It could not be said, for example, that slavery was unjust because everyone necessarily owns themselves.
} 
to explain why, in that same society, stealing somebody's money (where the money had been obtained through honest work and not from the use of slaves) was a rightsviolation.

We might be tempted to simply postulate that there are certain moral constraints, independent of the actual laws, that the state must respect in order for its establishment of a given class of property rights to be legitimate; one of these constraints would be that a person may not be the property of another person. But this is precisely to abandon thesis (ii) of the Extreme Legalist View. Once we abandon (ii), we are left with no reason for recognizing the state's ownership claim on tax revenues. The state's revenue-collection method is not one that would normally be taken, intuitively, as a legitimate way of acquiring property. That is why Murphy and Nagel introduced the Extreme Legalist View of property to begin with.

The upshot is that only the moderate view of property rights is plausible. On this view, the objective moral principles governing property leave certain matters unsettled - how much light one may shine at a neighbor's property, how high above someone else's land one may fly, and so on. It is for laws and conventions to settle those matters. But the laws and conventions are not completely unconstrained; they must respect certain broad normative truths about property. There is room for disagreement as to precisely which aspects of property rights are natural and which are conventional. The success of the Nagel-Murphy argument depends upon how extensive the role of law is in shaping the contours of property rights. Can the state legitimately define property rights such that the state owns precisely the funds that it wishes to collect as taxes?

There is reason to believe that the answer is no. The funding methods used by actual states, and likely to be used for the foreseeable future, do not merely judiciously define property rights in some unsettled area. Nor does the state limit itself to infringing upon certain controversial alleged property rights, such as copyrights, rights to control airspace, or the right to bequeath property. Rather, the standard revenue-collection methods used by the state infringe upon core property claims in paradigmatic ways. Suppose that I use threats of kidnaping and imprisonment to coerce my neighbors into giving me $10 \%$ of their income. I am not merely laying claim to a portion of certain unusual, controversial forms of income; I lay claim to a portion of every neighbor's income, from whatever source derived. It is not indeterminate whether this is a rights violation or not; this is not one of those matters, like the amount of airspace one may claim above one's home, that is left unsettled by our ethical intuitions. This is just a clear case of a property rights violation (and this would remain true even if my action violated no law). There is room for disagreement as to what are the legitimate ways of acquiring property, but on any normal (not radically revisionary) conception, there will be some legitimate ways of acquiring goods, such that one who acquires goods in one of those ways has a property right in them. Since I am coercively transferring goods from my neighbors regardless of how they acquired those goods, I am violating any normal conception of property rights.

Property rights are not absolute; if I had some urgent use for the money, the rightsviolation might be justified. So defenders of taxation could argue that the state must resort to taxation to fund its operations, and thus to prevent a general breakdown of 
social order. Whether this is true or not is open to debate, ${ }^{19}$ but that is not my concern here. Here, I am addressing only views according to which taxation is not even a rights violation at all.

\section{Conclusion}

Wealth redistribution financed by taxation is a violation of the property rights of taxpayers. In response to recent objections to this thesis, I have argued:

a. The fact that one produces wealth through cooperation with other members of society, rather than through entirely solitary efforts, does not prevent one from acquiring an unencumbered property right in the money one receives from market transactions, given that the others on whom one relies make their contributions voluntarily and receive the compensation in exchange for which they agree to make those contributions.

b. The fact that the state provides valuable services, even services that are necessary to one's productivity (if indeed this is the case), does not prevent taxation from constituting a rights violation. It is possible for a rights violation to have beneficial consequences; it is also possible for a person to steal money that he (the thief) helped the victim to obtain in the first place.

c. There is a tension in any libertarian position that countenances taxation to fund the minimal state while criticizing taxation used to fund wealth redistribution. Libertarians should resolve the tension by holding either that the minimal state is unjustified, that the minimal state can be financed voluntarily, or that the harms averted by the minimal state are sufficiently dire to justify the violation of property rights.

d. It is plausible to hold that (provided that the state is legitimate in general) the state has a legitimate role in defining property rights. However, the state's definition of property rights is not morally unconstrained; it must respect certain broad, prepolitical moral norms governing ownership. These broad norms establish certain kinds of behavior as paradigmatic property-rights violations, including the sort of behavior in which the state is engaged when it taxes citizens.

None of this proves that wealth redistribution could not be ethically justified, all things considered. What it shows is that there is an important consideration against redistribution. It remains possible that humanitarian or other values outweigh the property rights of taxpayers. The preceding reasoning has practical importance nonetheless, because it raises the threshold for the justification of redistributive taxation. Theft can be justified, but this requires fairly serious reasons; theft is not justified, for example, merely because the thief has a somewhat better use for some property than the original owner. Similarly, taxation might be justified, but this would require fairly serious reasons, something stronger than merely that the state has a somewhat better use for the

\footnotetext{
${ }^{19}$ See Huemer 2013.
} 
money than the taxpayers. ${ }^{20}$

\section{References}

Barry, Christian. 2014. "Redistribution," Stanford Encyclopedia of Philosophy, ed. Edward N. Zalta, <http://plato.stanford.edu/archives/spr2014/entries/redistribution/>. C-SPAN. 2012. "President Obama Campaign Rally in Roanoke," July 13, <http://www.c-span.org/video/?307056-2/president-obama-campaign-rallyroanoke>. Accessed May 6, 2014.

Friedman, David. 1989. The Machinery of Freedom, $2^{\text {nd }}$ ed. LaSalle, Ill.: Open Court.

Holmes, Stephen and Cass Sunstein. 1999. The Cost of Rights: Why Liberty Depends on Taxes. New York: W.W. Norton.

Huemer, Michael. 2013. The Problem of Political Authority: An Examination of the Right to Coerce and the Duty to Obey. New York: Palgrave Macmillan.

Locke, John. [1690] 1980. Second Treatise of Government, ed. C.B. Macpherson. Indianapolis, Ind.: Hackett.

Murphy, Liam and Thomas Nagel. 2002. The Myth of Ownership: Taxes and Justice. Oxford: Oxford University Press.

Nagel, Thomas. 1981. "Libertarianism without Foundations," pp. 191-205 in Jeffrey Paul (ed.), Reading Nozick: Essays on Anarchy, State and Utopia. Totowa, N.J.: Rowman \& Littlefield.

Nozick, Robert. 1974. Anarchy, State, and Utopia. New York: Basic Books.

Rawls, John. 1999. A Theory of Justice, revised edition. Cambridge, Mass.: Harvard University Press.

Scanlon, Thomas. 1981. "Nozick on Rights, Liberty, and Property," pp. 107-29 in Jeffrey Paul (ed.), Reading Nozick: Essays on Anarchy, State and Utopia. Totowa, N.J.: Rowman \& Littlefield.

Wellman, Christopher Heath. 2005. "Samaritanism and the Duty to Obey the Law," pp. 1-89 in Christopher Heath Wellman and A. John Simmons, Is There a Duty to Obey the Law? New York: Cambridge University Press.

Zelenak, Lawrence. 2003. "The Myth of Pretax Income," Michigan Law Review 101: 2261-74.

${ }^{20}$ I would like to thank Bas van der Vossen for his helpful and insightful remarks on the draft of this paper. 